\title{
Interspecific chromosomal divergences in the genus Characidium (Teleostei: Characiformes: Crenuchidae)
}

\author{
José Carlos Pansonato Alves, Luiz Ricardo de Souza Paiva, \\ Claudio Oliveira and Fausto Foresti
}

Karyotypes of seven fish species of the genus Characidium, three of them studied for the first time, were characterized using conventional cytogenetic techniques (Giemsa staining, Ag-NOR, and C-banding). All species presented a diploid number of $2 \mathrm{n}=50$, with only metacentric and submetacentric chromosomes, as observed in all Characidium species studied. In two species cells with one to three B chromosomes were observed. All species analyzed have a single NOR-bearing chromosome pair with morphological differences among them. Characidium cf. zebra shows heterochromatic blocks restricted to the pericentromeric regions of all chromosomes denoting the absence of a sex chromosome system. On the other hand, the species Characidium lanei, C. pterostictum, C. lauroi, C. oiticicai, C. schubarti, and Characidium sp., besides presenting pericentromeric heterochromatic blocks, exhibited large interstitial and/or terminal heterochromatic blocks, and a ZZ/ZW sex chromosome system. The constitutive heterochromatin seems to play a relevant role in the chromosome differentiation process of the studied species, mainly in relation to the sex chromosomes. The geographical isolation of the rivers in which the species were sampled, associated with their way of life restricted to headwaters environments, may have favored the process of fixation of different karyotypes found in each of the analyzed species.

Os cariótipos de sete espécies de peixes do gênero Characidium, três estudadas pela primeira vez, foram caracterizados com o uso das técnicas citogenéticas convencionais (Giemsa, Ag-RONs e bandamento-C). Todas as espécies apresentaram número diplóide de $2 \mathrm{n}=50$ cromossomos, com predominância de cromossomos dos tipos meta e submetacêntricos. Nesse estudo foi também observada a presença de até três cromossomos B em células de duas espécies, C. oiticicai e C. pterostictum. O bandamento $\mathrm{C}$ e o tratamento com nitrato de prata revelaram significativas diferenças nos cariótipos das espécies analisadas. A espécie Characidium cf. zebra apresenta heterocromatina restrita às regiões pericentroméricas dos cromossomos e ausência de heteromorfismos cromossômicos relacionados à diferenciação sexual, enquanto as espécies Characidium lanei, C.pterostictum, C. lauroi, C. oiticicai, C. schubarti e Characidium sp., evidenciaram, além de blocos pericentroméricos também observados em Characidium cf. zebra, grandes blocos heterocromáticos intersticiais e/ou terminais e sistema cromossômico de diferenciação sexual do tipo ZZ-ZW. A heterocromatina constitutiva parece exercer papel relevante no processo de diferenciação cromossômica destas espécies, principalmente em relação à diferenciação de cromossomos sexuais. O isolamento geográfico dos rios em que essas espécies foram amostradas, bem como o seu modo de vida restrito às regiões de cabeceira, podem ter favorecido o processo de diferenciação cromossômica e a fixação dos cariótipos particulares encontrados em cada uma das espécies analisadas.

Key words: Karyotypic evolution, Sex chromosomes, B-chromosomes, Ag-NORs.

\section{Introduction}

Fish represent the sister group to modern vertebrates and most species are gonochoristic and do not present differentiated sex chromosomes (Devlin \& Nagahama, 2002) or are hermaphrodite. Polygenic sex determination may occur in most species of this group of organisms and is considered a basal mechanism among the sex determination systems (Ohno, 1974). However, fish species that present morphologically differentiated sex chromosomes, mainly those found in the Neotropical region (Oliveira et al., 2007), reveal a great variability of systems. The differentiated sex chromosomes may have developed independently in several lineages of Neotropical fishes, because their occurrence is sporadic and probably recent in certain groups. In some families, such as Erythrinidae and Parodontidae, different heteromorphic sex chromosome systems were identified among their representatives (Moreira-Filho et al., 1993; Born $\&$ Bertollo, 2000).

Characidium, the most specious genus of the subfamily

Departamento de Morfologia, Instituto de Biociências, Universidade Estadual Paulista (UNESP), 18618-000 Botucatu, SP, Brazil. pansonato@ibb.unesp.br 
Characidiinae (Crenuchidae), comprises about 50 species with a wide distribution in the freshwaters of the Neotropical region located between Panama and Argentina (Buckup, 2003). The phylogenetic position of this group has recently changed, since Characidiinae was considered a member of Hemiodontidae, a subfamily of Characidae, and also an independent family. A cladistic analysis suggested that Characidiinae and Crenuchinae belong to the monophyletic family Crenuchidae (Buckup, 1998).

Cytogenetic studies in this group are scarce, recent, and limited to some species of the genus Characidium (Miyazawa \& Galetti Jr., 1994; Maistro et al., 1998, 2004; Centofante et al., 2001, 2003; Silva \& Maistro, 2006; Vicari et al., 2008; Noleto et al., 2009). The analyzed species present a conserved karyotypic macrostructure, showing a constant diploid number of $2 \mathrm{n}=50$ chromosomes and a predominance of metacentric and submetacentric chromosomes. On the other hand, the identification of a sex determination system of the ZZ/ZW type (Maistro et al., 1998, 2004), the occurrence of supernumerary chromosomes (Maistro et al., 1998, 2004), the presence of NORs (nucleolus organizing region) in different chromosomes pairs (Maistro et al., 1998, 2004), and even the occurrence of triploid individuals (Centofante et al., 2001) ascertain the great karyotypic variability of Characidium.

The purpose of the present study was to enhance the knowledge of the cytogenetic structures of species of the genus Characidium, describing and comparing the karyotypic constitution of seven species occurring in the Southern and Southeastern Brazil. The data obtained are used to propose a new hypothesis about karyotypic differentiation and diversification processes within this fish group.

\section{Material and Methods}

Seven fish species belonging to the genus Characidium, captured in different river basins in Southern and Southeastern Brazil, were analyzed (Fig. 1, Table 1). The individuals were fixed in $10 \%$ formaldehyde, conserved in $70 \%$ Ethanol, and after identification, deposited in the fish collection of Laboratório de Biologia e Genética de Peixes (LBP), UNESPBotucatu, São Paulo, Brazil (Table 1).

Mitotic chromosome preparations were obtained from renal tissue and gills using the "air-drying" technique (Foresti et al., 1981). Metaphase chromosomes were analyzed under an optical photomicroscope (Olympus BX61) and the images were captured by Image Pro Plus, 6.0 software (MediaCybernetics). The chromosome morphology was determined according to the arm ratio proposed by Levan et al. (1964). Chromosomes were classified as metacentric (m), submetacentric (sm), subtelocentric (st) and acrocentric (a) and arranged in the karyotype by type in decreasing order of size. The analysis of NORs by silver nitrate staining followed the technique proposed by Howell \& Black (1980) and Cbanding was accomplished following the protocol described by Sumner (1972).

Characidium zebra appears as a widespread and polymorphic species usually identified in the literature by the incorrect name of $C$. fasciatum (Buckup, 2003). The type locality of C. zebra is the Maripicru Creek, a branch of the Ireng River, Guyana, and there is no study defining the limits of its occurrence (Buckup \& Reis, 1997). In the present study, individuals morphologically similar to Characidium zebra were provisionally called Characidium $\mathrm{cf}$. zebra.

\section{Results}

The cytogenetic analysis of Characidium showed a conserved diploid number of $2 n=50$, with a predominance of metacentric and submetacentric chromosomes (Figs. 2-5). In Characidium cf. zebra, the first metacentric chromosome pair was the largest among the karyotypes analyzed, showing a significative difference in size when compared with the second pair. Other species analyzed presented the first two metacentric pairs with similar size, and C.pterostictum also presented a pair of acrocentric chromosomes. Except for $C$. cf. zebra, all the species presented heteromorphisms involving the chromosomes of pair 2 in females, while in males, this chromosome pair was homomorphic. Two species presented $\mathrm{B}$ chromosomes that ranged from zero to three in C. oiticicai, and from zero to two in C. pterostictum (Figs. $2 \mathrm{c}$ and 3 ), which showed to be consistent within each individual.

C-banding revealed significant differences in heterochromatin patterns among the species. Characidium cf. zebra presented a small amount of constitutive heterochromatin restricted to the pericentromeric areas of all chromosomes (Fig. 2b). Besides the pericentromeric heterochromatin observed in C. cf. zebra, the other six species presented large interstitial and/or terminal blocks and a sex differentiation chromosome system of the ZZ/ZW type, represented by the heteromorphic chromosome pair number

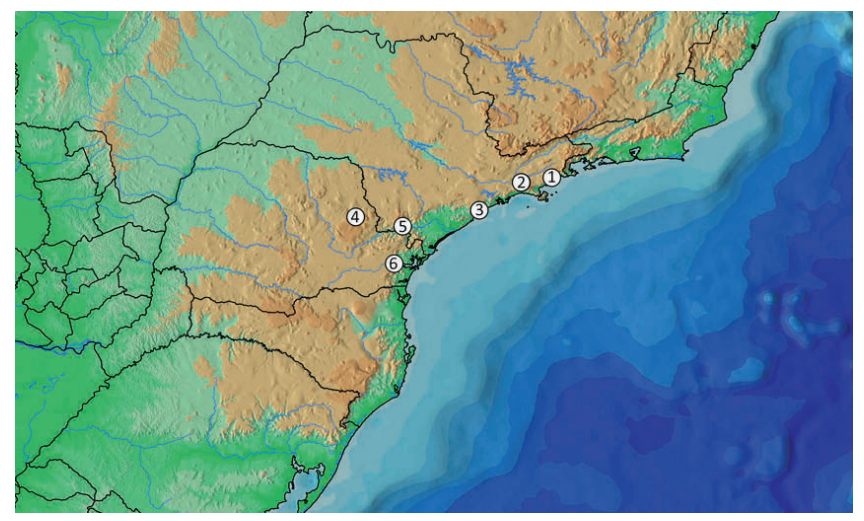

Fig. 1. Partial map of South America showing the Characidium species collection sites. 1 = Ubatuba, SP (Characidium lauroi), 2 = Salesópolis, SP (Characidium oiticicai and Characidium cf. zebra), 3 = Itanhaém, SP (Characidium sp.), 4 = Jaguariaíva, PR (Characidium schubarti), $5=$ Apiaí, SP (Characidium pterostictum), $6=$ Morretes, PR (Characidium lanei). 
Table 1. Specimens of Characidium analyzed in this study. $\mathrm{LBP}=$ catalog number of vouchers; $\mathrm{F}=$ female; $\mathrm{M}=$ male; $\mathrm{SP}=\mathrm{São}$ Paulo State; $\mathrm{MG}=$ Minas Gerais State; $\mathrm{PR}=$ Paraná State.

\begin{tabular}{lcclccc}
\hline \multicolumn{1}{c}{ Species } & Map Point & LBP & \multicolumn{1}{c}{ Sample Localities } & F & M & \multicolumn{1}{c}{ Coordinates } \\
\hline C. lauroi & 1 & 8741 & tributary of rio Grande, Ubatuba, SP & 4 & 1 & $23^{\circ} 23^{\prime} 42^{\prime \prime} \mathrm{S} 45^{\circ} 07^{\prime} 17^{\prime \prime} \mathrm{W}$ \\
C. oiticicai & 2 & 8703 & rio Paraitinga, Salesópolis, SP & 15 & 5 & $23^{\circ} 30^{\prime} 40^{\prime \prime} \mathrm{S} 45^{\circ} 51^{\prime} 32^{\prime \prime} \mathrm{W}$ \\
C. cf. zebra & 2 & 8704 & rio Paraitinga, Salesópolis, SP & 12 & 7 & $23^{\circ} 30^{\prime} 40^{\prime \prime} \mathrm{S} 45^{\circ} 51^{\prime} 32^{\prime \prime} \mathrm{W}$ \\
Characidium sp. & 3 & 6818 & tributary of rio Preto, Itanhaém, SP & 18 & 8 & $24^{\circ} 10^{\prime} 39^{\prime \prime} \mathrm{S} 46^{\circ} 50^{\prime} 56^{\prime \prime} \mathrm{W}$ \\
C. schubarti & 4 & 8702 & rio Cinco Réis, Jaguariaiva, PR & 10 & 7 & $25^{\circ} 17^{\prime} 46^{\prime \prime} \mathrm{S} 49^{\circ} 44^{\prime} 56^{\prime \prime} \mathrm{W}$ \\
C. pterostictum & 5 & 7367 & rio Betari, Apiaí, SP & 15 & 5 & $24^{\circ} 33^{\prime} 03^{\prime \prime} \mathrm{S} 48^{\circ} 40^{\prime} 49^{\prime \prime} \mathrm{W}$ \\
C. lanei & 6 & 8700 & córrego Cari, Morretes, PR & 11 & 7 & $25^{\circ} 26^{\prime} 29^{\prime \prime} \mathrm{S} 48^{\circ} 32^{\prime} 28^{\prime \prime} \mathrm{W}$ \\
\hline
\end{tabular}

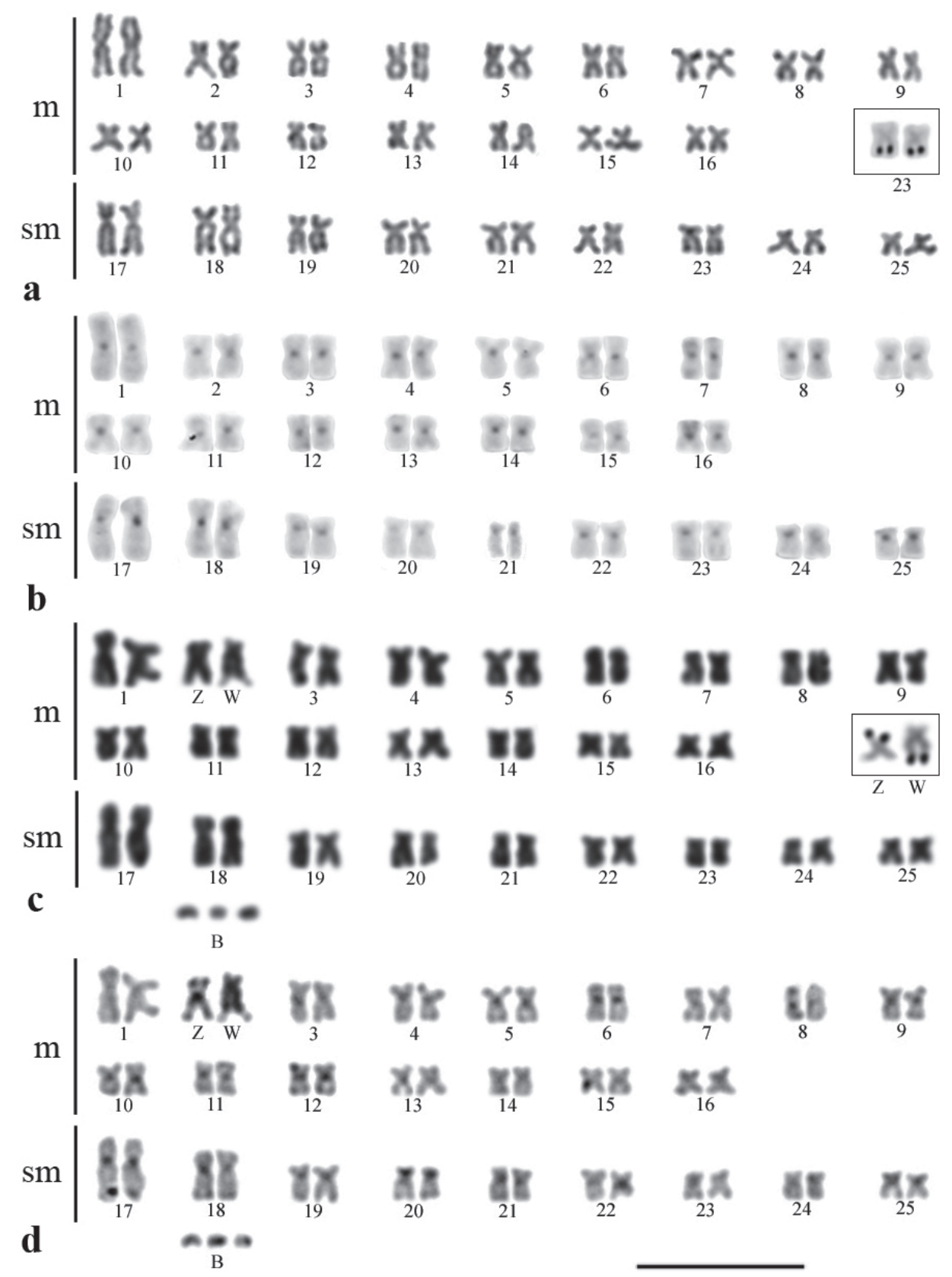

Fig. 2. Karyotypes of female specimens of Characidium cf. zebra and Characidium oiticicai from Salesópolis, SP, after conventional Giemsa staining (a, c) and C-banding (b, d), respectively. Note the differential patterns of heterochromatic blocks on the chromosomes and the differentiated sex chromosomes and heterochromatic B-chromosomes in Characidium oiticicai. In the box, the NOR-bearing chromosomes. Scale bar $=10 \mu \mathrm{m}$. 


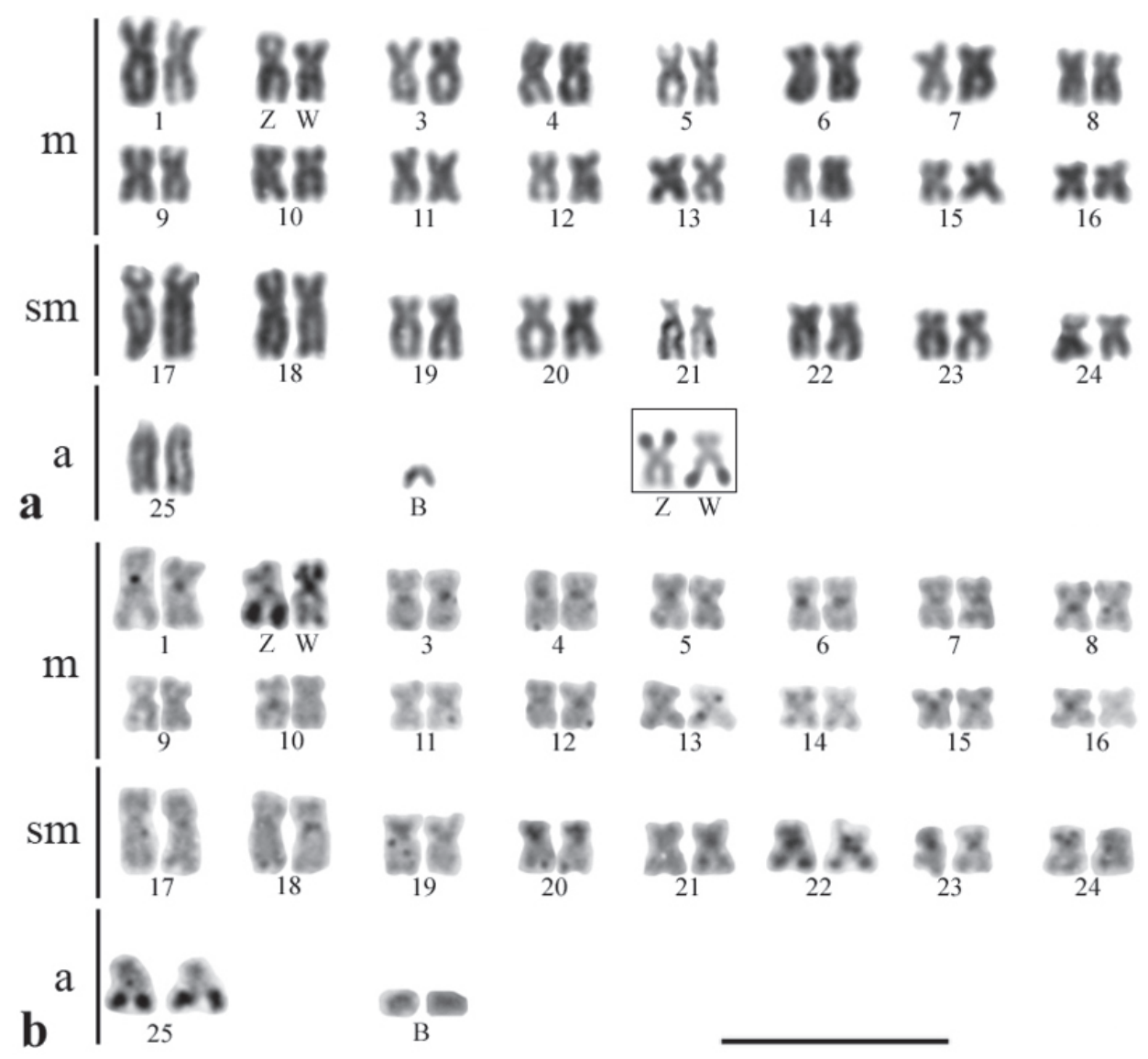

Fig. 3. Karyotypes of female specimens of Characidium pterostictum from Apiaí, SP, after conventional Giemsa staining (a) and C-banding (b). Note the differential patterns of heterochromatic blocks on the $\mathrm{Z}$ and $\mathrm{W}$ chromosomes and the heterochromatic B-chromosomes In the box, the $\mathrm{Z}$ and $\mathrm{W}$ chromosomes carrying the NORs in an inverted position. Scale bar $=10 \mu \mathrm{m}$.

2 observed in females of these species (Figs. 2c-d, Figs. 3-5).

The exclusive acrocentric chromosomes found in $C$. pterostictum showed large heterochromatic blocks in the terminal position (Fig. 3b). B chromosomes of C. oiticicai and $C$. pterostictum were shown to be partially heterochromatic (Figs. 2d and 3b).

The silver nitrate staining demonstrated that all the species of Characidium under analysis possess single NORs (Table 2; highlighted in Figs. 2-5). Characidium cf. zebra presented two marks at the final position on the long arm of pair 23 (Fig. 2a). The other species presented ribosomal sites associated with the sex chromosomes, $\mathrm{Z}$ chromosome has the NORs at the terminal position on the short arms, and the $\mathrm{W}$ chromosome has the NORs located at the terminal position on the long arms (Fig. 6).

\section{Discussion}

In the present study, the karyotypes of $C$. oiticicai, $C$. schubarti, and Characidium sp. were studied for the first time, increasing the number of species karyotyped in the genus to ten. The species studied presented a conserved karyotypic macrostructure, mainly in relation to their diploid number and the presence of metacentric and submetacentric chromosomes. Nevertheless, the presence of B chromosomes in C. pterostictum and C. oiticicai, the occurrence of sex chromosomes in most of the analyzed species, the occurrence of NORs associated with sex chromosomes, and the occurrence of a pair of acrocentric chromosomes in $C$. pterostictum (Table 2) reinforce the evidence already postulated for some species of Characidium, which suggested the existence of a great chromosome variability among the representatives of this genus (Maistro et al., 1998, 2004; Centofante et al., 2001, 2003; Vicari et al., 2008; Noleto et al., 2009).

The species Characidium zebra is considered morphologically basal in the phylogeny of Characidium, presenting several plesiomorphic characters (Buckup, 1993). In that sense, the karyotype of this species could also be characterized as basal for the group under study and chromosome variations observed in the other species could be explained by the occurrence of several structural chromosome rearrangements. Thus, the acrocentric pair found in C. pterostictum could have arisen from the event of a pericentric inversion in a submetacentric chromosome pair, followed by the accumulation of heterochromatin in the region 


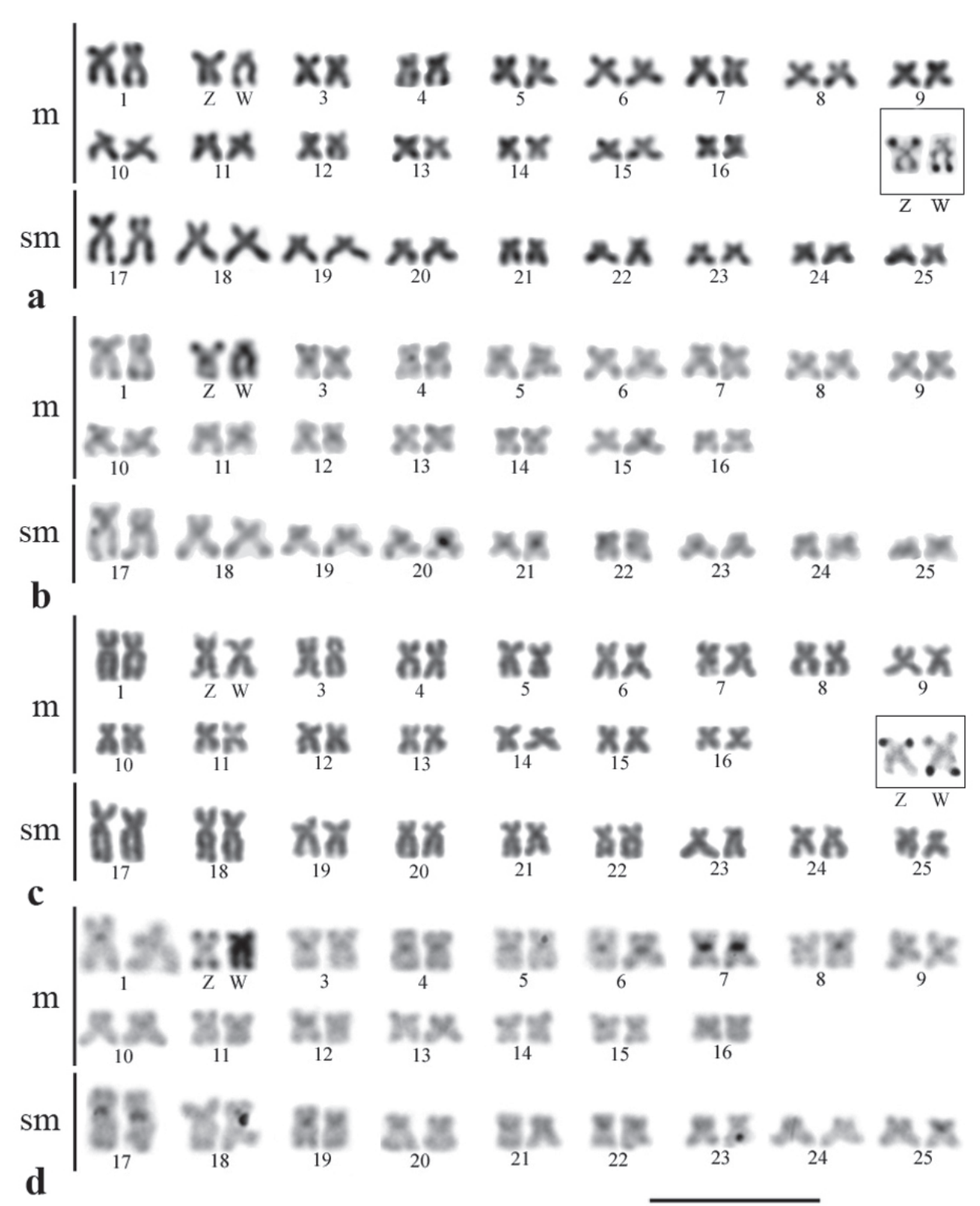

Fig. 4. Karyotypes of female specimens of Characidium sp. from Itanhaém, SP, and Characidium schubarti from Jaguariaiva, PR, after conventional Giemsa staining ( $a, c)$ and C-banding (b, d), respectively. Note conspicuous heterochromatic blocks in the centromeric region of some chromosome pairs and the differentiated sex chromosomes, being the $\mathrm{W}$ almost completely heterochromatic in both species. In the box, the $\mathrm{Z}$ and $\mathrm{W}$ chromosomes carrying the NORs in an inverted position. Scale bar $=10 \mu \mathrm{m}$.

where the rearrangement occurred. The size variation observed between pairs 1 and 2 of Characidium cf. zebra, which are not found in the remaining species, could be related to the formation of sex chromosomes identified as the second pair in those species, where the process of heterochromatinization of both $\mathrm{Z}$ and $\mathrm{W}$ resulted in an increase in size of these chromosomes.

Maistro et al. $(1998,2004)$ had previously described the occurrence of sex chromosome systems of the ZZ/ZW type in Characidium sp. aff. C. gomesi, cited as Characidium cf. fasciatum, collected in a tributary of the Paranapanema River. In this population, sex chromosomes were represented by submetacentric chromosomes of pair 19 and the Z chromosome, besides showing identical size and morphology, presented a pericentromeric heterochromatic block, while chromosome W was completely heterochromatic. Centofante et al. (2001) reported a second case of sex chromosome heteromorphism in Characidium gomesi among samples captured at the Paiol Grande Stream, a tributary of the rio Grande basin, in Serra da Mantiqueira. In this species, the Z chromosome was identified as a metacentric chromosome of pair number 2, with pericentromeric heterochromatin, while the $\mathrm{W}$ chromosome was described as a small, submetacentric, and completely heterochromatic chromosome. In 


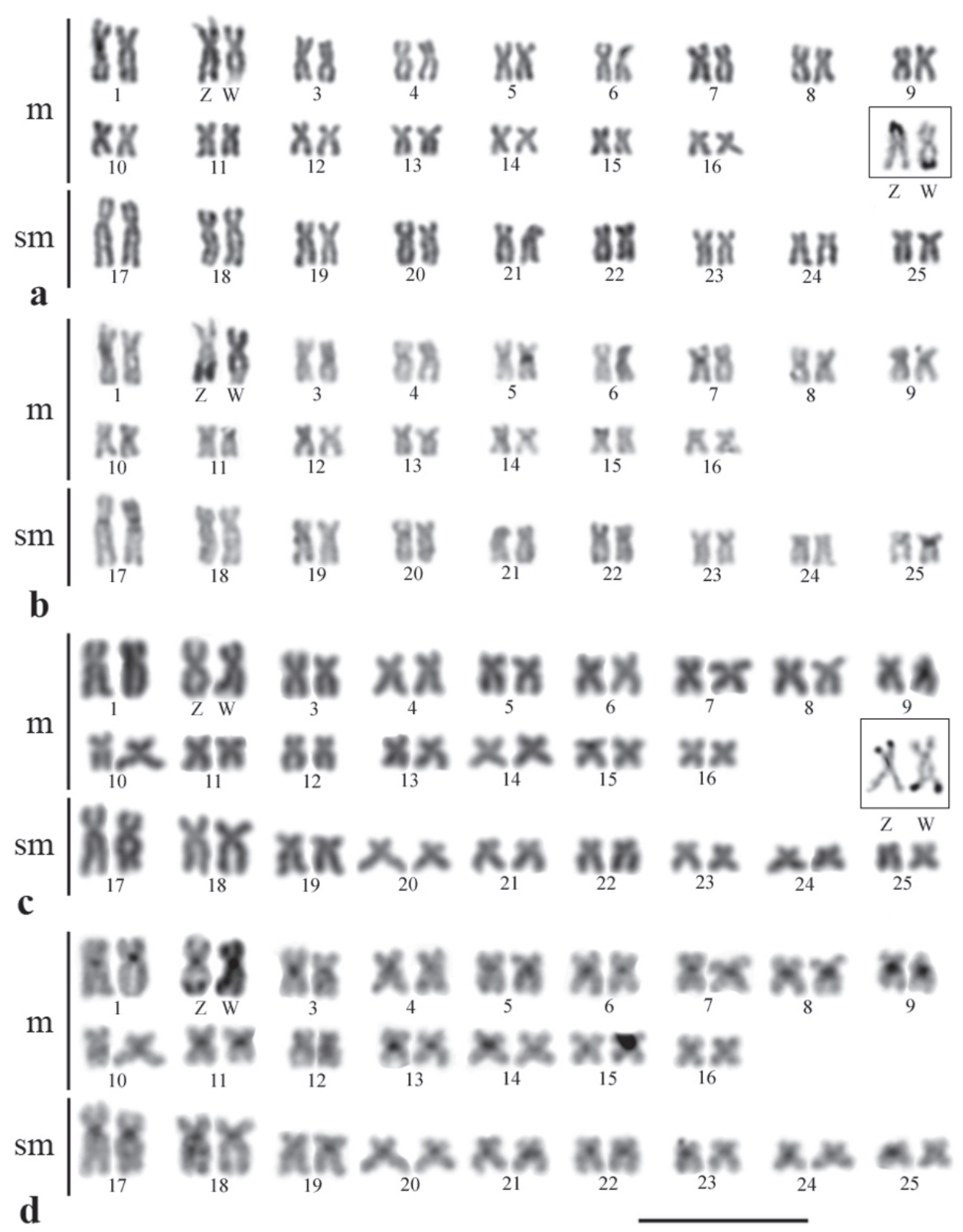

Fig. 5. Karyotypes of the female specimen of Characidium lauroi from Ubatuba, SP, and Characidium lanei from Morretes, PR, after conventional Giemsa staining ( $\mathrm{a}, \mathrm{c}$ ) and C-banding (b, d), respectively. Note the different patterns of heterochromatic blocks on the chromosomes and the differentiated sex chromosomes, being the $\mathrm{W}$ almost completely heterochromatic in both species. In the box, the $\mathrm{Z}$ and $\mathrm{W}$ chromosomes carrying the NORs in an inverted position. Scale bar $=10 \mu \mathrm{m}$.

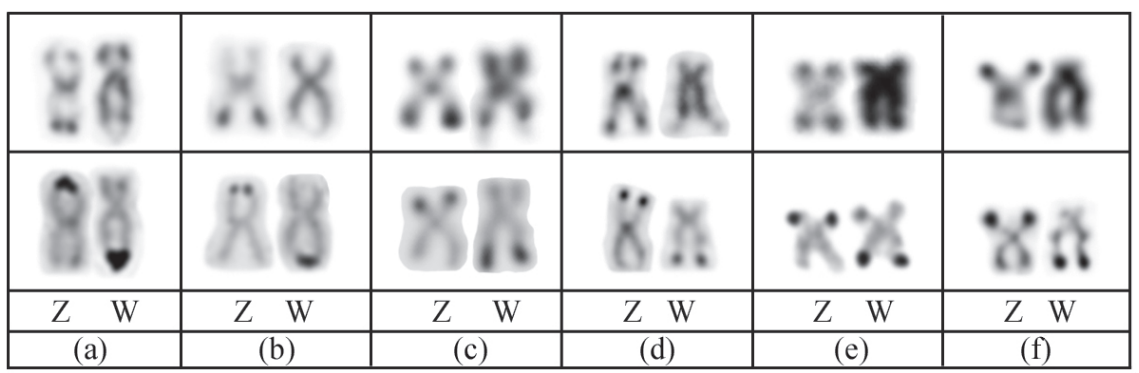

Fig. 6. Z an W sex chromosomes of the Characidium species analyzed in this study, after C-banding (first row) and silver nitrate staining (second row). Note the different distribution of the heterochromatin, mainly in the $\mathrm{W}$ chromosome in (a) $C$. schubarti, (b), Characidium sp., (c) C.pterostictum, (d) C. oiticicai, (e) C. lanei, and (f) C. lauroi. 
Characidium sp. cf. C. alipioi, the Z chromosome presented pericentromeric and telomeric heterochromatin and the $\mathrm{W}$ chromosome was totally heterochromatic (Centofante et al., 2003). In this species, sex chromosomes also present the same size and morphology and correspond to the chromosomes of pair number 1 in the karyotype. The analysis of Characidium cf. gomesi from the Quebra Perna Stream, Tibagi River basin, conducted by Vicari et al. (2008) registered another occurrence of ZZ/ZW chromosomes, where Z was represented by a metacentric chromosome with pericentromeric heterochromatin and $\mathrm{W}$ by a subtelocentric chromosome totally heterochromatic.

The occurrence of a simple sex determination system originating from a differential heterochromatinization process in one of the sex chromosomes is a common event among fishes (Oliveira et al., 2007). The heterochromatinization process, when observed in one of the chromosomes of the previously homomorphic pair in a region adjacent to the sexual determining sequence, enables the suppression of recombination events and favors the independent evolution of this chromosome and/or chromosome region (John, 1988; Rice, 1996; Steinemann \& Steinemann, 1992, 2001). Vicari et al. (2008) consider the existence of a protosex chromosome pair for some Characidium species and, both the $\mathrm{Z}$ and $\mathrm{W}$ chromosomes would have undergone shape and size modifications, probably due to duplications, deletions and/ or inversions, in relation to the putative ancestor condition. Thus, the heterochromatinization mechanism appears to play an important role in the differentiation of $\mathrm{W}$ chromosome from the protosex chromosome among populations/species

Table 2. Cytogenetic data available for the genus Characidium ( $2 \mathrm{n}=50$ chromosomes). Ref. $=1$. Miyazawa \& Galetti Jr. (1994); 2. Maistro et al. (1998); 3. Silva \& Maistro (2006); 4. Centofante et al. (2001); 5. Centofante et al. (2003); 6. Vicari et al. (2008); 7. Noleto et al. (2009); 8. Present study. $\mathrm{SC}=\mathrm{Sex}$ Chromosomes System; NOR Position on Chromosomes $\mathrm{T}=$ terminal. $\mathrm{I}=$ interstitial; $\mathrm{BC}=$ Number of B Chromosomes; $\mathrm{SP}=$ São Paulo State; $\mathrm{MG}=$ Minas Gerais State; $\mathrm{PR}=$ Paraná State.

\begin{tabular}{|c|c|c|c|c|c|c|c|}
\hline Species & Sample Localities & $\mathrm{SC}$ & Ag-NOR-bearing pair & Hydrographic system & $\mathrm{BC}$ & Karyotypic formula & Ref. \\
\hline C. sp. cf. C. alipioi & córrego Ribeirão Grande, SP & ZZ/ZW & $16(\mathrm{~T})$ & Paraíba do Sul River & - & $\begin{array}{l}\text { males } 30 \mathrm{~m}+20 \mathrm{sm} \\
\text { females } 30 \mathrm{~m}+20 \mathrm{sm}\end{array}$ & 5 \\
\hline C. sp. aff. C. gomesi & rio Pardo, SP & $\mathrm{ZZ/ZW}$ & $17(\mathrm{~T})$ & Paranapanema River & $1-4$ & $\begin{array}{l}\text { males } 32 \mathrm{~m}+18 \mathrm{sm} \\
\text { females } 32 \mathrm{~m}+18 \mathrm{sm}\end{array}$ & 2 \\
\hline C. sp. aff. C. gomesi & rio Quinta, SP & $\mathrm{ZZ/ZW}$ & $17(\mathrm{~T})$ & Paranapanema River & $1-4$ & $\begin{array}{l}\text { males } 32 \mathrm{~m}+18 \mathrm{sm} \\
\text { females } 32 \mathrm{~m}+18 \mathrm{sm}\end{array}$ & 2 \\
\hline C. gomesi & rio Machado, MG & - & $17(\mathrm{~T})$ & Grande River & - & $\begin{array}{l}\text { males } 32 \mathrm{~m}+18 \mathrm{sm} \\
\text { females } 32 \mathrm{~m}+18 \mathrm{sm}\end{array}$ & 3 \\
\hline C. gomesi & córrego Paiol Grande, SP & $\mathrm{ZZ/ZW}$ & $18(\mathrm{I})$ & Grande River & - & $\begin{array}{l}\text { males } 32 \mathrm{~m}+18 \mathrm{sm} \\
\text { females } 31 \mathrm{~m}+19 \mathrm{sm}\end{array}$ & 4 \\
\hline C. cf. gomesi & rio Quebra Perna, PR & $\mathrm{ZZ/ZW}$ & multiple & Tibagi River & - & $\begin{array}{c}\text { males } 32 \mathrm{~m}+18 \mathrm{sm} \\
\text { females } 31 \mathrm{~m}+18 \mathrm{sm}+1 \mathrm{st}\end{array}$ & 6 \\
\hline C. lagosantensis & rio Mogi-Guaçu, SP & - & - & Mogi-Guaçu River & - & $\begin{array}{c}\text { males } 32 \mathrm{~m}+18 \mathrm{sm} \\
\text { females } 32 \mathrm{~m}+18 \mathrm{sm}\end{array}$ & 1 \\
\hline C. lanei & rio Barroca & $\mathrm{ZZ/ZW}$ & $2(\mathrm{~T})$ & coastal rivers & & $\begin{array}{l}\text { males } 32 \mathrm{~m}+16 \mathrm{sm}+2 \mathrm{a} \\
\text { females } 31 \mathrm{~m}+17 \mathrm{sm}+2 \mathrm{a}\end{array}$ & 7 \\
\hline C. lanei & córrego Cari, PR & $\mathrm{ZZ/ZW}$ & $2(\mathrm{~T})$ & coastal rivers & - & $\begin{array}{l}\text { males } 32 \mathrm{~m}+18 \mathrm{sm} \\
\text { females } 31 \mathrm{~m}+19 \mathrm{sm}\end{array}$ & 8 \\
\hline C. lauroi & córrego Ribeirão Grande, SP & - & 5 and 23 & Paraíba do Sul River & - & $\begin{array}{l}\text { males } 24 m+24 s m+2 s t \\
\text { females } 24 m+24 s m+2 s t\end{array}$ & 5 \\
\hline C. lauroi & tributary of rio Grande, SP & $\mathrm{ZZ/ZW}$ & $2(\mathrm{~T})$ & Tietê River & - & $\begin{array}{c}\text { males } 32 \mathrm{~m}+18 \mathrm{sm} \\
\text { females } 31 \mathrm{~m}+18 \mathrm{sm}+1 \mathrm{a}\end{array}$ & 8 \\
\hline C. oiticicai & rio Paraitinga, SP & $\mathrm{ZZ/ZW}$ & $2(\mathrm{~T})$ & coastal rivers & $1-3$ & $\begin{array}{l}\text { males } 32 \mathrm{~m}+18 \mathrm{sm} \\
\text { females } 31 \mathrm{~m}+19 \mathrm{sm}\end{array}$ & 8 \\
\hline C.pterostictum & Reserva Jataí, SP & - & - & Ribeira do Iguape River & - & $\begin{array}{l}\text { males } 32 \mathrm{~m}+16 \mathrm{sm}+2 \mathrm{st} \\
\text { females } 32 \mathrm{~m}+16 \mathrm{sm}+2 \mathrm{st}\end{array}$ & 1 \\
\hline C.pterostictum & rio Betari, SP & $\mathrm{ZZ/ZW}$ & $2(\mathrm{~T})$ & Ribeira do Iguape River & $1-2$ & $\begin{array}{l}\text { males } 32 m+16 s m+2 a \\
\text { females } 32 m+16 s m+2 a\end{array}$ & 8 \\
\hline C. schubarti & rio Cinco Réis, PR & $\mathrm{ZZ/ZW}$ & $2(\mathrm{~T})$ & Paranapanema River & - & $\begin{array}{l}\text { males } 32 \mathrm{~m}+18 \mathrm{sm} \\
\text { females } 32 \mathrm{~m}+18 \mathrm{sm}\end{array}$ & 8 \\
\hline C. cf. zebra & Reserva Jataí, SP & - & $25(\mathrm{~T})$ & Ribeira do Iguape River & - & $\begin{array}{l}\text { males } 32 \mathrm{~m}+18 \mathrm{sm} \\
\text { females } 32 \mathrm{~m}+18 \mathrm{sm}\end{array}$ & 1 \\
\hline C. cf. zebra & rio Passa Cinco, SP & - & $25(\mathrm{~T})$ & Tietê River & 1 & $\begin{array}{l}\text { males } 32 \mathrm{~m}+18 \mathrm{sm} \\
\text { females } 32 \mathrm{~m}+18 \mathrm{sm}\end{array}$ & 1 \\
\hline C.cf. zebra & rio Piracicaba, SP & - & $25(\mathrm{~T})$ & Tietê River & - & $\begin{array}{l}\text { males } 32 \mathrm{~m}+18 \mathrm{sm} \\
\text { females } 32 \mathrm{~m}+18 \mathrm{sm}\end{array}$ & 1 \\
\hline C. cf. zebra & rio Machado, MG & - & $23(\mathrm{~T})$ & Grande River & - & $\begin{array}{l}\text { males } 32 \mathrm{~m}+18 \mathrm{sm} \\
\text { females } 32 \mathrm{~m}+18 \mathrm{sm}\end{array}$ & 3 \\
\hline C.cf. zebra & córrego Paiol Grande, SP & - & 23 (I) & Grande River & - & $\begin{array}{l}\text { males } 32 \mathrm{~m}+18 \mathrm{sm} \\
\text { females } 32 \mathrm{~m}+18 \mathrm{sm}\end{array}$ & 4 \\
\hline C. cf. zebra & rio Paraitinga, SP & - & $23(\mathrm{I})$ & upper Tietê River & - & $\begin{array}{l}\text { males } 32 \mathrm{~m}+18 \mathrm{sm} \\
\text { females } 32 \mathrm{~m}+18 \mathrm{sm}\end{array}$ & 8 \\
\hline Characidium sp. & tributary of rio Preto, SP & $\mathrm{ZZ/ZW}$ & $2(\mathrm{~T})$ & coastal rivers & - & $\begin{array}{l}\text { males } 32 \mathrm{~m}+18 \mathrm{sm} \\
\text { females } 32 \mathrm{~m}+18 \mathrm{sm}\end{array}$ & 8 \\
\hline
\end{tabular}


in an independent pathway. In the present study, the identification and analysis of sexual chromosomes in C. lanei, C. pterostictum, C. lauroi, C. oiticicai, C. schubarti, and Characidium sp., which characterize $\mathrm{Z}$ and $\mathrm{W}$ heteromorphic chromosome systems in distinct stages of differentiation, supports the propositions postulated by Centofante et al. $(2001,2003)$ and Vicari et al. (2008) that heterochromatinization events could have occurred in the ancestors of these species and that sex chromosomes differentiated independently during the speciation process. This could explain the differences found among the level of heterochromatinization in some species analyzed, possibly reinforcing the hypothesis of a common origin for heteromorphic sex chromosomes followed by an independent process of differentiation in the Characidium species.

The presence of rDNA segments in sex chromosomes is not a rare event and has been described in some groups of organisms. Cistrons of ribosomal genes $5.8 \mathrm{~S}, 18 \mathrm{~S}$, and $28 \mathrm{~S}$ that form the nucleolar organizer regions in animals and are usually stained with silver nitrate (Ag-NORs), were observed in sex chromosomes, including insects as Drosophila (Pelegrini et al., 1977), beetles (Juan et al., 1993) and flies (Parise-Maltempi \& Avancini, 2001); mammals (YonenagaYassuda et al., 1983; Oshida et al., 1999), and also plant chromosomes (Nakayama et al., 2001). Reports on the presence of Ag-NORs in fish sex chromosomes are restricted to Fundulus diaphanus (Howell \& Black, 1979), Salvelinus alpinus (Reed \& Phillips, 1997), Hoplias malabaricus (Born $\&$ Bertollo, 2000), Triportheus guentheri (Artoni \& Bertollo, 2002), Triportheus venezuelensis (Nirchio et al., 2007) and Characidium lanei (Noleto et al., 2009). In the rainbow trout Oncorhynchus mykiss, which presents a sex determination system of the XX/XY type, the 5S ribosomal DNA was also observed on the X chromosome (Moran et al., 1996).

The occurrence of NORs in $\mathrm{Z}$ and $\mathrm{W}$ chromosomes of $C$. lauroi, C. oiticicai, C. lanei, C. pterostictum, C. schubarti, and Characidium sp. could possibly have occurred prior to the process of sexual chromosome differentiation in those species, and even preceded the heterochromatinization of these chromosomes, suggesting that all these sex chromosomes originated once in this group of Characidium. Among another group of species composed of Characidium sp. cf. C. alipioi (Centofante et al., 2003), Characidium gomesi (Centofante et al., 2001), Characidium sp. aff. $C$. gomesi (Maistro et al., 1998, 2004), and Characidium cf. gomesi (Vicari et al., 2008) Ag-NORs are not related to sex chromosomes and are usually located at the terminal position on the long arms of a large metacentric pair or in a multiple form distributed on several chromosomes.

The variation in the diploid number due to the presence of B chromosomes observed in C. pterostictum and $C$. oiticicai has been reported for other species of this genus. Miyazawa \& Galetti Jr. (1994) reported the presence of one individual presenting one euchromatic acrocentric B chromosome in Characidium cf. zebra, among 28 individuals analyzed. Maistro et al. $(1998,2004)$ described the frequent presence of one to four entirely heterochromatic acrocentric B chromosomes in Characidium sp. aff. C. gomesi. B chromosomes identified in C. pterostictum and C. oiticicai in the present study showed an irregular constitutive heterochromatin pattern in their structure, which could characterize an intermediate heterochromatinization process or modifications that occurred in the chromosomes during the diversification process.

Different mechanisms have been proposed to explain the origin, differentiation, and maintenance of $\mathrm{B}$ chromosomes in different organisms (Jones \& Rees, 1982). However, the existence of entirely heterochromatic B chromosomes seems to characterize the heterochromatinization process as a very common event, frequently found in most of the cases reported (Venere et al., 1999). Morphological differences and diverse heterochromatic patterns observed in B chromosomes of the Characidium species suggest an independent origin process for these chromosomes, followed by specific, internal modifications. Contrarily to the fully heterochromatic chromosomes found in Characidium sp. aff. C. gomesi, the partially heterochromatic B chromosomes found in C. oiticicai and $C$. pterostictum could have originated from recent events, i.e., from heterochromatic or euchromatic elements followed by modifications in the chromatin distribution patterns. On the other hand, the constitutive heterochromatin does not seem to have participated in the origin and development of the extra chromosome observed in Characidium cf. zebra, which is euchromatic (Venere et al., 1999).

Centofante et al. (2001, 2003) and Vicari et al. (1998) consider that the evolution and establishment of the sex chromosome systems in the genus Characidium might be intimately associated with the existence of biogeographic barriers. According to Weitzman et al. (1988), the main rivers of southern and southeastern Brazil are currently separated by barriers that hinder the dispersion of species and populations, thence favoring the occurrence of events that determine the isolation of the groups. In such context, exclusive karyotypic constitutions and different sex chromosome systems in fish could be fixed independently in different species of a genus, promoting intraspecific diversification and contributing to the speciation process of different groups. In the genus Characidium, which normally presents species with and without ZZ/ZW sex chromosome systems living in sympatry (Centofante et al., 2001, 2003), a plausible hypothesis is that the occurrence of headwaters capture events may have contributed to the present situation in the species diversification and distribution, once they usually occupy the same environment.

Although different events may have influenced the karyotypic diversification process in the genus Characidium, the constitutive heterochromatin seems to play an expressive role in the chromosome differentiation of the analyzed species, and the study of this chromatin portion using molecular techniques could bring new information to improve our understanding of the evolutionary relationships within this group. 


\section{Acknowledgements}

This work was supported by Fundação de Amparo à Pesquisa do Estado de São Paulo (FAPESP), Conselho Nacional de Desenvolvimento Científico e Tecnológico (CNPq) and Coordenação de Aperfeiçoamento de Pessoal de Nível Superior (CAPES). The authors are grateful to Renato Devide for collaboration in field and laboratory activities.

\section{Literature Cited}

Artoni, R. F. \& L. A. C. Bertollo. 2002. Evolutionary aspects of the ZZ/ZW sex chromosome system in the Characidae fish, genus Triportheus. A monophyletic state and NOR. Heredity, 89: 15-19.

Born, G. G. \& L. A. C. Bertollo. 2000. An XX/XY sex chromosome system in a fish species, Hoplias malabaricus, with a polymorphic NOR-bearing $\mathrm{X}$ chromosome. Chromosome Research, 8: 111-118.

Buckup, P. A. 1993. The monophyly of the Characidiinae, a Neotropical group of characiform fishes (Teleostei: Ostariophysi). Zoological Journal of the Linnean Society, 108: 224-245.

Buckup, P. A. 1998. Relationships of the Characidiinae and phylogeny of characiform fishes (Teleostei: Ostariophysi). Pp. 123-144. In: Malabarba, L. R., R. E. Reis, R. P. Vari, C. A. S. Lucena \& Z. M. S. Lucena (Eds.). Phylogeny and Classification of Neotropical Fishes. Porto Alegre, Edipucrs, 603p.

Buckup, P. A. 2003. Family Crenuchidae (South American darters). Pp. 87-95. In: Reis, R. E., S. O. Kullander \& C. J. Ferraris Jr. (Eds.). Check List of the Freshwater Fishes of South and Central America. Porto Alegre, Edipucrs, 729p.

Buckup, P. A. \& R. E. Reis. 1997. Characidiin genus Characidium (Teleostei, Characiformes) in southern Brazil, with description of three new species. Copeia, 1997(3): 531-548.

Centofante, L., L. A. C. Bertollo, P. A. Buckup \& O. Moreira Filho. 2003. Chromosomal divergence and maintenance of sympatric Characidium fish species (Crenuchidae, Characidiinae). Hereditas, 138: 213-218.

Centofante, L., L. A. C. Bertollo \& O. Moreira Filho. 2001. Comparative cytogenetics among sympatric species of Characidium (Pisces, Characiformes). Diversity analysis with the description of a ZW sex chromosome system and natural triploidy. Caryologia, 54: 253-260.

Devlin, R. H. \& Y. Nagahama. 2002. Sex determination and sex differentiation in fish: an overview of genetic, physiological, and environmental influences. Aquaculture, 208: 191-364.

Foresti, F., L. F. Almeida-Toledo \& S. A. Toledo Filho. 1981. Polymorphic nature of nucleolus organizer regions in fishes. Cytogenetics and Cell Genetics, 31: 137-144.

Howell, W. M. \& D. A. Black. 1979. Location of the nucleolus organizer regions on the sex chromosomes of the banded killifish, Fundulus diaphanus. Copeia, 1979(3): 544-546.

Howell, W. M. \& D. A. Black. 1980. Controlled silver staining of nucleolus organizer regions with a protective colloidal developer: A 1-step method. Experientia, 36: 1014-1015.

John, B. 1988. The biology of heterochromatin. Pp. 1-147. In: Verma, R. S. (Ed.). Heterochromatin: molecular and structural aspects. Cambridge University Press, 301p.

Jones, R. N. \& H. Rees. 1982. B Chromosome. London, Academic Press, 266p.
Juan, C., J. Pons \& E. Petitpierre. 1993. Localization of tandemly repeated DNA sequences in beetle chromosomes by fluorescence in situ hybridization. Chromosome Research, 1: 167-174.

Levan, A., K. Fredga \& A. A. Sandberg. 1964. Nomenclature for centromeric position on chromosomes. Hereditas, 52: 201-220.

Maistro, E. L., C. M. Jesus, C. Oliveira, O. Moreira Filho \& F. Foresti. 2004. Cytogenetic analysis of A- B- chromosomes and ZZ/ZW sex chromosomes of Characidium gomesi (Teleostei, Characiformes, Crenuchidae). Cytologia, 69: 181-186.

Maistro, E. L., E. P. Mata, C. Oliveira \& F. Foresti. 1998. Unusual occurrence of a ZZ/ZW sex-chromosome system and supernumerary chromosomes in Characidium cf. fasciatum (Pisces, Characiformes, Characidiinae). Genetica, 104: 1-7.

Miyazawa, C. S. \& P. M. Galetti Jr. 1994. First cytogenetical studies in Characidium species (Pisces: Characiformes, Characidiinae). Cytologia, 59: 73-79.

Moran, P., J. L. Martinez, E. Garcia-Vasquez \& A. M. Pendas. 1996. Sex chromosome linkage of 5S rDNA in rainbow trout (Oncorhynchus mykiss). Cytogenetics Cell Genetic, 75: 145-150.

Moreira-Filho, O., L. A. C. Bertollo \& P. M. Galetti Jr. 1993. Distribution of sex chromosome mechanisms in Neotropical fish and description of a ZZ/ZW system in Parodon hilarii (Parodontidae). Caryologia, 46: 115-125.

Nakayama, S., M. Fujishita, T. Sone \& K. Ohyama. 2001. Additional locus of rDNA sequence specific to the X chromosome of the liverwort, Marchantia polymorpha. Chromosome Research, 9: 469-473.

Nirchio, M., C. Oliveira, I. A. Ferreira, A. Granado \& E. Ron. 2007. Extensive polymorphism and chromosomal characteristics of ribosomal DNA in the characid fish Triportheus venezuelensis (Characiformes, Characidae). Genetics and Molecular Biology, 30(1): 25-30.

Noleto, R. B, A. P. Amorin, M. R. Vicari, R. F. Artoni \& M. M. Cestari. 2009. An unusual ZZ/ZW sex chromosome system in Characidium fishes (Crenuchidae, Characiformes) with the presence of rDNA sites. Journal of Fish Biology, 75: 448-453.

Ohno, S. 1974. Protochordata, Cyclostomata and Pisces. Pp. 4663. In: John, B. (Ed.) Animal Cytogenetics.Gebrüder Borntraeger, Berlin. 92p.

Oliveira, C., F. Foresti \& L. F. Almeida-Toledo. 2007. Karyotypic evolution in Neotropical fishes. Pp. 111-164. In: Pisano, E., C. Ozouf-Costaz, F. Foresti \& B. G. Kapoor (Eds.). Fish Cytogenetics. Enfield, Science Publisher, 502p.

Oshida, T., J. Shindo \& M. C. Yoshida. 1999. Nor-bearing Y chromosome in American beaver, Castor canadensis (Rodentia, Castoridae). Chromosome Science, 3: 117-118.

Parise-Maltempi, P. P. \& R. M. P. Avancini. 2001. C-banding and FISH in chromosomes of the blow flies Chrysomya megacephala and Chrysomya putoria (Diptera, Calliphoridae). Memórias do Instituto Oswaldo Cruz, 96: 371-377.

Pellegrini, M., J. Manning \& N. Davidson. 1977. Sequence arrangement of the rDNA of Drosophila melanogaster. Cell, 10: 213-214.

Reed, K. M. \& R. B. Phillips. 1997. Polymorphism of the nucleolus organizer region (NOR) on the putative sex chromosomes of artic char (Salvelinus alpinus) is not sex related. Chromosome Research, 5: 221-227.

Rice, W. R. 1996. Evolution of the Y sex chromosome in animals. Bioscience, 46: 331-343.

Silva, A. R. \& E. L. Maistro. 2006. Cytogenetic divergence between two sympatric species of Characidium (Teleostei, Characiformes, Crenuchidae) from the Machado river, Minas Gerais, Brazil. Genetics and Molecular Biology, 29: 459-463. 
Steinemann, M. \& S. Steinemann. 1992. Degenerating Y chromosome of Drosophila miranda: a trap for retrotransposons. Proceedings of the National Academy of Sciences, 89: 7591-7595.

Steinemann, S. \& M. Steinemann. 2001. Biased distribution of repetitive elements: a landmark for neo-Y chromosome evolution in Drosophila miranda. Cytogenetics Cell Genetics, 93: 228-233.

Sumner, A. T. 1972. A simple technique for demonstrating centromeric heterochromatin. Experimental Cell Research, 75: 304-306.

Venere, P. C., P. M. Galetti Jr. \& C. S. Miyazawa. 1999. New cases of supernumerary chromosomes in Characiform fishes. Genetics and Molecular Biology, 22(3): 345-349.

Vicari, M. R., R. F. Artoni, O. Moreira Filho \& L. A. C. Bertollo. 2008. Diversification of a ZZ/ZW sex chromosome system in Characidium fish (Crenuchidae, Characiformes). Genetica, 134: 311-317.

Weitzman, S. H., N. A. Menezes \& M. J. Weitzman. 1988. Phylogenetic biogeography of the Glandulocaudini (Teleostei, Characiformes, Characidae) with comments on the distributions of other freshwater fishes in Eastern and Southeastern Brazil. Pp. 379-427. In: Vanzolini, P. E. \& W. R. Heyer (Eds.). Proceedings of a Workshop on Neotropical Distribution Patterns. Academia Brasileira de Ciências, 488p.

Yonenaga-Yassuda, Y., M. F. L. Assis, S. Kasahara, M. L. L'abbate \& M. J. Souza. 1983. Nucleolar organizer regions in Akodon arviculoides (Cricetidae, Rodentia): Evidence for the activity of rDNA genes in both X chromosomes of females. Cytogenetics Cell Genetics, 35: 143-147.

Accepted January 5, 2010

Published March 31, 2010 